\title{
システムトラスにおける設計・施工情報の統計的分析 ANALYSIS OF DESIGN AND CONSTRUCTION INFORMATION FOR SYSTEM TRUSS
}

\author{
藤田正則*，岩田 衛**，和田章*** \\ Masanori FUJITA, Mamoru IWATA and Akira WADA
}

\begin{abstract}
The System Truss Design Standards which offer a selection of standardized component are utilized for the design of a system truss. However, individual judgement is also required in the economic and construction aspects. For example, the economic aspects, structural properties and the construction method become even clearer by a quantitative comparative study of the performance data based on actual projects of a system truss. This paper statistically analyzes the design and construction information which stipulates the capacity of a system truss, and provides basic data in order to appropriately evaluate the design conditions and to determine the rationality of construction of a system truss.
\end{abstract}

Keywords : system truss, information, design, construction, component システムトラス，情報，設計，施工，部品

\section{1.はじめに}

球形の節点に鋼管部材を接合するシステムトラスは、スポーツ施 設やハンガー等の大規模建築物に使用され、既に多くの実績を残し ている。通常、意匠性のある屋根を構成する構造体として使用され ることが多い。システムトラスが普及するに至った理由は、主に、 システムトラスが意匠性に優れていること、現場に扔いて熟練労働 者を必要としないこと、現場溶接や多本数の高力ボルトを用いた接 合法に比較して1本ボルトのため作業性が良いこと、現場での組み 立ての際の品質管理及び製造管理が容易であることによるものであ る12) 3)。システムトラスの構造設計は、各種の基・規準等に照ら し合わせて、このシステムのために作った設計規準(4)用いて行わ れる。しかし、この設計規準はシステムトラスの部品選択を規定し たものであり、実際の構造物の設計を進めるためには、経済性や施 工性の面において設計者の判断や決断が個々に要求される。たとえ ば、部分円筒の形状をした屋根構造の設計を行う場合、曲率半径の 大小は曲げ応力と膜応力の発生割合を支配するので、スパンが大き くなるにつれて曲率半径を小さくし、膜応力状態を強めることによ り合理的な設計が可能となる5) 6) 7) 8)。このような力学的特性と経済 性の関連は、部材サイズや応力性状等を実績デー夕により定量的に 比較検討することでよりいっそう明らかになる。また、施工法の種
類によって境界条件、応力性状が異なる場合もあり、実際の施工例を 分析することで、各種の施工法の持つ特徴、合理性の違いを明らかに することができる。

本論では、システムトラスの実施例において構造物の性能を規定す る設計・加工・施工情報〉 のうち、設計・施工情報の統計的分析を行 い、システムトラスに関する設計条件の適切な評価や合理的な構造物 の性能を把握するための基礎デー夕を提供するものである。なお、 これらのデータは一般には公開されることがないため、著者らが手が けたものにとどまっているが、さらに広くデータを蓄積することがで きれば、システムトラスに限らずスペースフレームの設計・研究に役 立つものと考える。

\section{2. 設計・施工情報の概要}

2 . 1 設計・施工情報

ここで取り上げるシステムトラスとは、図 1 に示すような、鋼管 部材（弦材及び斜材）、接合部中核（ノード）、接合機構（1本ボル ト・ワッシャ等）からなる構成部品を立体的に組み、任意の屋根形状 を形成するものである。このシステムトラスの合理的な構造設計及び 施工を行うためには下記に示す最適な条件を把握する必要がある。

1) グリッド長さ及びデプス（デプスとは上弦材と下弦材の芯心間距
* 新日本製鐵株式会社建築事業部 工修

**新日本製鐵株式会社建築事業部 工博

*** 東京工業大学建築物理研究センター 教授・工博
Nippon Steel Corporation, M. Eng.

Nippon Steel Corporation, Dr. Eng.

Prof., Structural Engineering Research Center, Tokyo Institute of Technology, Dr. Eng. 
離をさす）の設定（以下、グリッド長さ及びデプスをグリッ ド形状という)

2) 境界条件

3 ) 部品

4) 施工法

5 ）塗装仕様

ここでは、上記の条件を規定する情報について取り上げる。

\section{2 共通項目}

システムトラスは主として体育館、プール、アイススケート場等の スポーツ施設や広場屋根、サンバイザー、アトリウム等のプラザや、 また、博覧会、展示場、ホール等の多目的ホールに使用されている。 過去15年間における実施例（200件）の中で各種用途の中から、図 $2 に$ 示すような 4 種類の屋根形状について112件のデー夕分析（温暖地域 98件、多雪地域14件）を行った。これらのデー夕を分析するにあた り、下記の点を共通項目とする。

1) 屋根形状には、平版、部分中筒、寄棟、曲面版、切妻、シェル、 方形、任意曲面等の様々あるが、ここでは、これらの形状のう ち、力学的特性の異なる 4 種類の形状 (平版 43 件、部分円筒 31 件、寄棟16件、曲面版22件の実施例の計112件）を選定する。こ こで、曲面版とは、スパン・ライズ比 2.5 以上の 2 方向曲率を有 する形状のうち、ドームや水平投影で矩形や楕円等も含む。

2) グリッド形状は 4 角錐グリッド10) からなる複層システムトラスを 対象とする。 4 角錐グリッドにおける程と横のグリッド長さは異 なる場合が多いので、桁行方向の最大部材となるグリッド長さを 代表とする。3 角錐グリッドは、多雪地域や平面形状が多角形 の場合等に限られるため、ここでは对象とない。

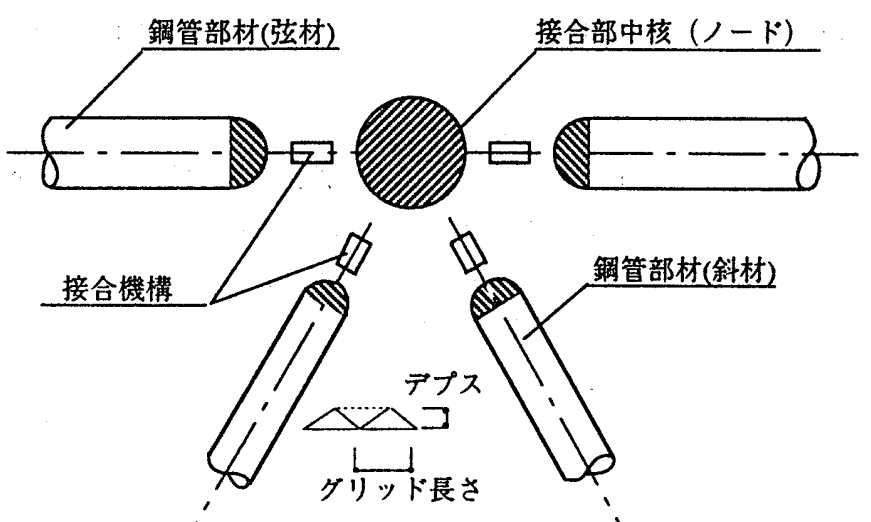

図1 システムトラス接合部の基本構成
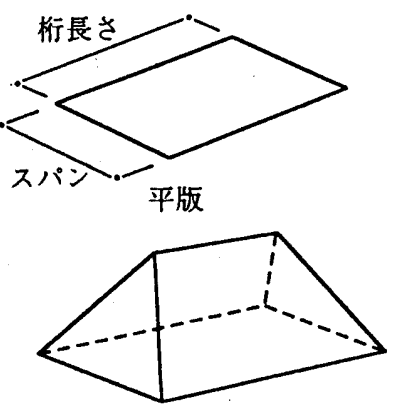

奇棟
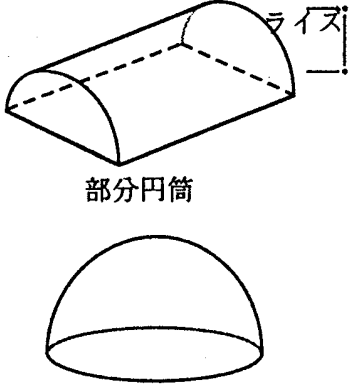

曲面版
図2 屋根形状
3）材質は鋼材を対象とする。実施例において、ステンレス、アルミ ニウム等の材質のものはごく稀である。

4 ）屋根面積は500 $\mathrm{m}^{2}$ から $7000 \mathrm{~m}^{2}$ の範囲を対象とする。 $500 \mathrm{~m}^{2}$ より小さい規模では、境界条件が多様であること、ま た、 $7000 \mathrm{~m}^{2}$ より大きい規模では、システムトラスの標準部品を 超えることが多いので、ここでは対象としない。

5）荷重は鋼 管部材に曲げモーメント及びせん断力の二次応力が生 じないように節点に作用するものとする。また、クレーンや局部 的に大きな荷重等の特殊条件を除いている。

6）境界条件は 2 辺支持、 4 辺支持、 4 点支持を対象とする（図3）。

$7 ）$ 上記の条件を満たすシステムトラスの最小スパンは $16.0 \mathrm{~m} 、$ 最大 スパンは87.1m、最高高さは7.0〜 38.2mである。

\section{3、設計・施工情報の特性}

2 節で示したシステムトラスの実施例における設計・施工情報の概 要に基づき、グリッド形状、境界条件、部品、施工法、塗装仕様の各 情報について代表的なデー夕を示し、その特性を述べる（表 1 a,b,c,d) 。

3. 1 グリッド形状

システムトラスのグリッド形状は屋根形状を構成する基本ユニット であり、システムトラス全体の剛性や各部品の強度の他、意匠上の制 約や経済性を考慮して決定する必要がある。以下、システムトラスの グリッド形状を規定する情報において、スパン・デプス比（ $\alpha=$

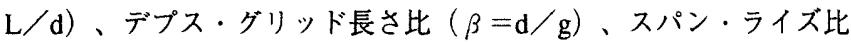
$(\gamma=\mathrm{L} / \mathrm{f})$ を設定する。なお、平版のライズは水勾配（1／100～ 5／100）程度であるため、 $\gamma$ の項は一とした。実施例の屋根面積は、

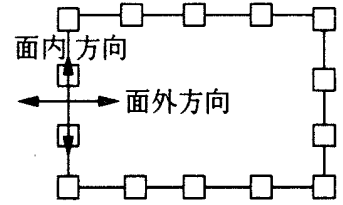

4 辺支持

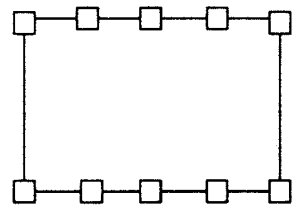

2 辺支持

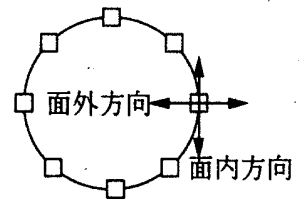

4 辺支持

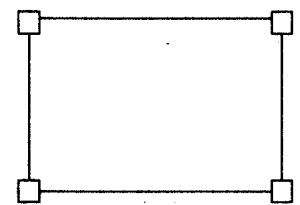

4 点支持
図3 境界情報

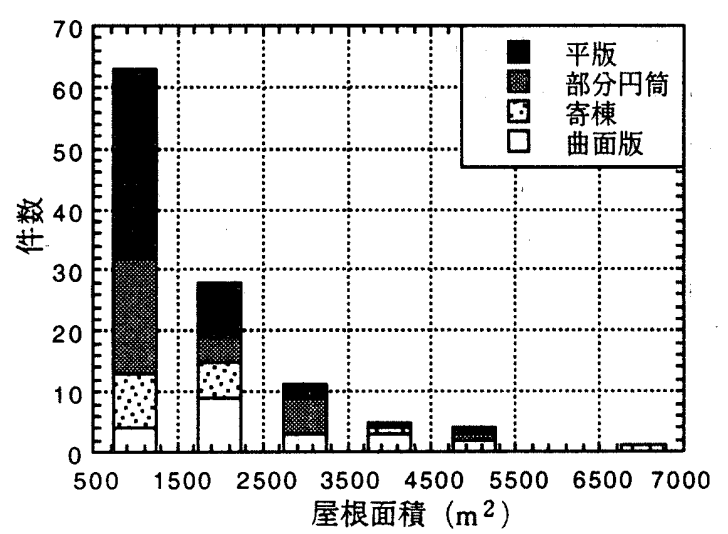

図4 屋根面積の分布 
表1 a 平版の実施例

\begin{tabular}{|c|c|c|c|c|c|c|c|c|c|c|c|c|c|c|c|c|c|c|c|c|c|}
\hline$=-8$ & $\pi n^{\prime} \cdot \lambda$ & 䉼長さB & "7'xd & 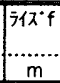 & 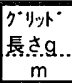 & \begin{tabular}{|l|}
$/ d$ \\
$* 11$
\end{tabular} & $\begin{array}{l}B / L \\
x_{2} \\
2\end{array}$ & \begin{tabular}{|l|}
$/ 9$ \\
$\times 3$ \\
$\times 3$
\end{tabular} & 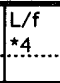 & \begin{tabular}{|l} 
最大 \\
部㷊经 \\
$\mathrm{mm}$
\end{tabular} & 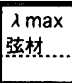 & $\begin{array}{l}\lambda \max \\
\text { 料执 }\end{array}$ & \begin{tabular}{|c|} 
境界 \\
$\therefore 5$ \\
..+- \\
\end{tabular} & 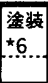 & \begin{tabular}{|c|} 
施工 \\
$\times 7$ \\
$7 ?$ \\
\end{tabular} & $\begin{array}{l}\text { 建设城 } \\
* 8\end{array}$ & $\begin{array}{l}\text { 用遂 } \\
\times 9 \\
\end{array}$ & 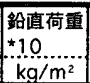 & \begin{tabular}{|c|} 
屋根面吻 \\
\hdashline $\mathrm{m}^{2}$ \\
$\mathrm{~m}^{2}$
\end{tabular} & $\begin{array}{c}\text { 最高高さn } \\
\cdots \\
\cdots\end{array}$ & 備考 \\
\hline $\mathrm{A} 01$ & 34.5 & 21.5 & 1.5 & 0.0 & 3.0 & 23.0 & 0.62 & 0.50 & $=$ & 114 & 78 & 86 & $\overline{2}$ & 1 & 1 & 3 & & 95 & & 14.5 & \\
\hline $\mathrm{AO2}$ & 24.0 & 37.2 & 2.4 & 0.0 & 3.0 & 10.0 & 1.55 & $\begin{array}{l}0.80 \\
\end{array}$ & - & 165 & 54 & $\frac{00}{105}$ & & 1 & 1 & 3 & 1 & 390 & \begin{tabular}{|l|}
892 \\
\end{tabular} & $\frac{14.5}{11.7}$ & 多霄地域 \\
\hline $\mathrm{AO} 3$ & 30.6 & 33.2 & 1.5 & 0.0 & 2.8 & 20.4 & 1.08 & 0.55 & $=$ & 139 & 57 & 62 & 2 & 1 & 1 & 1 & & 113 & 1218 & 11.7 & \\
\hline $\mathrm{AO} 4$ & 27.4 & 36.3 & 1.6 & 0.0 & 2.6 & 17.1 & 1.32 & 0.62 & - & 114 & 68 & 62 & 2 & 1 & 1 & 3 & & 95 & 995 & 15.4 & \\
\hline $\mathrm{AOS}$ & 28.8 & 37.8 & 1.5 & 0.0 & 2.8 & 19.2 & 1.31 & 0.54 & - & 139 & 59 & 71 & 2 & 1 & 1 & 1 & 1 & 120 & 1087 & 16.1 & \\
\hline $\mathrm{AOG}$ & 28.8 & 41.2 & 2.5 & 0.0 & 5.3 & 11.5 & 1.43 & 0.47 & - & 190 & 81 & 94 & 2 & 3 & 1 & 2 & 1 & 120 & 1187 & 18.0 & \\
\hline $\mathrm{A} 07$ & 37.1 & 33.6 & 1.8 & 0.0 & 3.2 & 20.6 & 0.91 & 0.56 & - & 165 & 57 & 83 & 2 & 1 & 1 & 3 & 1 & 80 & 1247 & 14.0 & \\
\hline $\mathrm{A08}$ & 35.2 & 35.2 & 2.0 & 0.0 & 3.0 & 17.6 & 1.00 & 0.67 & - & 165 & 53 & 75 & 2 & 3 & 1 & 2 & & 190 & 1243 & 16.3 & \\
\hline $\mathrm{AOg}$ & 30.6 & 36.0 & 2.0 & 0.0 & 3.0 & 15.3 & 1.18 & 0.67 & - & 216 & 41 & 61 & 2 & 3 & 1 & 2 & 1 & 400 & 1310 & 17.0 & 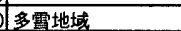 \\
\hline$A 10$ & 36.6 & 37.3 & 2.5 & 0.0 & 3.7 & 14.6 & 1.02 & 0.67 & - & 216 & 50 & 64 & 1 & 1 & 3 & 3 & 1 & 134 & 1366 & 18.0 & 施工時口ーラー支持 \\
\hline A11 & 33.4 & 47.6 & 2.0 & 0.0 & 3.4 & 16.7 & 1.43 & 0.59 & - & 114 & 87 & 90 & 2 & 1 & 1 & 1 & 1 & 80 & 1591 & 17.4 & \\
\hline $\mathrm{A} 12$ & 34.3 & 47.3 & 1.5 & 0.0 & 1.8 & 22.9 & 1.38 & 0.85 & - & 114 & 46 & 64 & 2 & 1 & 1 & 1 & 1 & 130 & 1626 & 14.3 & \\
\hline $\mathrm{A13}$ & 38.2 & 46.4 & 2.2 & 0.0 & 4.0 & 17.4 & 1.21 & 0.55 & - & 165 & 71 & 75 & 2 & 1 & 1 & 3 & & 95 & 1773 & 15.5 & \\
\hline A14 & 40.0 & 40.0 & 2.2 & 0.0 & 3.3 & 18.2 & 1.00 & 0.66 & - & 267 & 46 & 58 & 1 & 1 & 1 & 3 & 3 & 305 & 1878 & 12.0 & 多䨳地域 \\
\hline A15 & 39.0 & 50.0 & 2.1 & 0.0 & 3.0 & 18.6 & 1.28 & 0.70 & - & 190 & 46 & 98 & 2 & 1 & 3 & 1 & 1 & 95 & 1950 & 20.0 & 施工時口ーラー支持 \\
\hline A16 & 44.6 & 45.1 & 2.5 & 0.0 & 3.0 & 17.8 & 1.01 & 0.83 & - & 216 & 40 & 69 & 2 & 1 & 1 & 1 & 1 & 210 & 2017 & 22.2 & \\
\hline A17 & 27.6 & 35.6 & 2.1 & 0.0 & 3.5 & 13.1 & 1.29 & 0.61 & $=$ & 139 & 72 & 93 & 2 & 1 & 1 & 1 & & 95 & 986 & 17.2 & \\
\hline A18 & 26.4 & 33.6 & 2.4 & 0.0 & 3.8 & 11.0 & 1.27 & 0.64 & - & 165 & 68 & 92 & 2 & 1 & 1 & 3 & 1 & 370 & 887 & 13.5 & 多䨘地域 \\
\hline A19 & 25.6 & 32.0 & 2.0 & 0.0 & 3.2 & 12.8 & 1.25 & 0.63 & - & 165 & 57 & 54 & 2 & 1 & 1 & 3 & 1 & 310 & 819 & 16.2 & 多霄地域 \\
\hline A20 & 24.4 & 39.7 & 2.0 & 0.0 & 4.0 & 12.2 & 1.63 & 0.50 & - & 114 & 104 & 100 & 2 & 1 & 1 & 3 & 1 & 95 & 2183 & 8.8 & \\
\hline A21 & 34.0 & 36.1 & 2.0 & 0.0 & 4.0 & 17.0 & 1.06 & 0.50 & - & 139 & 83 & 115 & 2 & 1 & 1 & & 1 & 120 & 1226 & 9.0 & \\
\hline A22 & 45.0 & 56.0 & 3.0 & 0.0 & 4.5 & 15.0 & 1.24 & 0.67 & - & 165 & 96 & 127 & 2 & $\frac{1}{2}$ & 1 & & & 90 & 2520 & 17.0 & \\
\hline A23 & 23.7 & 47.8 & 1.7 & 0.0 & 2.0 & 13.9 & 2.02 & 0.85 & - & 101 & 57 & 85 & 2 & 2 & 1 & & 1 & 120 & 1150 & 11.4 & \\
\hline A24 & 39.0 & 55.0 & 2.0 & 0.0 & 3.1 & 19.5 & \begin{tabular}{|l|}
1.41 \\
\end{tabular} & 0.65 & - & 165 & 55 & 62 & 2 & 1 & 1 & 1 & 1 & 180 & 2141 & 17.8 & \\
\hline A25 & 22.0 & 35.1 & 2.0 & 0.0 & 2.9 & 11.0 & 1.60 & 0.68 & - & 139 & 63 & 74 & 2 & 1 & 1 & & 1 & 175 & 774 & 11.9 & \\
\hline A26 & 31.0 & 43.4 & 1.9 & 0.0 & 3.1 & \begin{tabular}{|l|l|}
16.4 \\
\end{tabular} & 1.40 & \begin{tabular}{|l|l|}
0.61 \\
\end{tabular} & - & 114 & 82 & 84 & 2 & 2 & 4 & & 3 & 125 & 1345 & 11.6 & \\
\hline A27 & 28.5 & 38.1 & 2.0 & 0.0 & 4.1 & \begin{tabular}{|l|}
14.3 \\
\end{tabular} & 1.34 & 0.49 & - & 139 & 87 & 117 & 2 & 1 & 1 & 3 & 1 & 120 & 1085 & 12.0 & \\
\hline A28 & 22.5 & 19.7 & 1.5 & 0.0 & 2.4 & 15.0 & 0.88 & 0.62 & - & 165 & 43 & 40 & 1 & 2 & 1 & & 2 & 120 & 574 & 12.5 & \\
\hline A29 & 26.6 & 42.9 & 1.6 & 0.0 & 2.7 & 16.6 & 1.61 & 0.60 & - & 139 & 55 & 81 & 2 & 1 & 2 & & 1 & 110 & 1326 & 11.1 & \\
\hline A30 & 27.0 & 27.0 & 1.5 & 0.0 & 3.0 & \begin{tabular}{|l|l}
18.0 \\
\end{tabular} & 1.00 & 0.50 & - & 190 & 46 & 40 & 3 & 2 & $\frac{4}{1}$ & 2 & 3 & 120 & $\frac{\mid 320}{729}$ & 7.0 & \\
\hline A31 & 32.0 & 37.5 & 2.0 & 0.0 & 3.7 & 16.0 & 1.17 & 0.54 & - & 190 & 56 & 58 & 2 & 1 & 1 & 1 & 1 & 115 & 1200 & 12.6 & \\
\hline A32 & 24.4 & 30.5 & 1.2 & 0.0 & 2.0 & 21.2 & 1.25 & 0.58 & - & 101 & 58 & 70 & 2 & 1 & 1 & 3 & 1 & 120 & 699 & 10.3 & \\
\hline A33 & 27.0 & 28.5 & 1.8 & 0.0 & 3.0 & 11.7 & 1.36 & 0.60 & - & 165 & 53 & 72 & 2 & 2 & 1 & 1 & 2 & 140 & 698 & 15.4 & \\
\hline A34 & 50.0 & 50.0 & 2.6 & 0.0 & 3.5 & 19.2 & 1.00 & 0.74 & - & 216 & 47 & 55 & 2 & 2 & 3 & & 3 & 140 & 2500 & 33.1 & 雄工腈口ーラー支持 \\
\hline A35 & 26.0 & 32.1 & 2.2 & 0.0 & 4.8 & 11.8 & 1.23 & 0.46 & - & 216 & 64 & 84 & 2 & & 3 & & 1 & 250 & 835 & 16.5 & 施工時口ーラー支持 \\
\hline A36 & 16.0 & 48.0 & 1.4 & 0.0 & 3.2 & 11.9 & 3.00 & 0.42 & - & 165 & 56 & 55 & 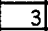 & & 4 & & 3 & 233 & 768 & 7.0 & \\
\hline A37 & 60.0 & 84.0 & 3.5 & 0.0 & 3.0 & 17.1 & 1.40 & 1.17 & - & 318 & 27 & 72 & 2 & 1 & 2 & & 3 & 130 & 5318 & 16.1 & 娒工時口ーラー支持 \\
\hline A38 & 25.6 & 37.0 & 1.4 & 0.0 & 2.6 & 18.3 & 1.45 & 0.54 & - & 139 & 54 & 76 & 2 & 1 & 1 & 3 & 1 & 180 & 947 & 11.1 & \\
\hline A39 & 20.5 & 29.5 & 1.9 & 0.0 & 3.0 & 11.1 & 1.44 & 0.63 & - & 165 & 52 & 58 & 2 & & 1 & & 1 & 205 & 606 & 11.9 & 多雷地域 \\
\hline A40 & 36.0 & 45.5 & 2.2 & 0.0 & 2.8 & 16.1 & 1.26 & 0.80 & - & 216 & 38 & 53 & 2 & & & & 4 & 250 & 1706 & 13.0 & 多雷地域 \\
\hline $\mathrm{A41}$ & 24.8 & 30.0 & 1.2 & 0.0 & 2.0 & 20.7 & 1.21 & 0.60 & E & 165 & 35 & 61 & 2 & & 1 & & 1 & 115 & 744 & 8.8 & \\
\hline A42 & 20.0 & 37.8 & 1.0 & 0.0 & 2.1 & 20.0 & 1.89 & 0.48 & - & 101 & 61 & 59 & 2 & & 1 & & & 85 & 756 & 15.5 & \\
\hline A43 & 26.0 & 32.5 & 1.4 & 0.0 & 2.8 & 18.6 & 1.25 & 0.50 & - & 165 & 49 & 94 & 2 & 7 & 1 & 3) & & 140 & 857 & 11.9 & \\
\hline
\end{tabular}

表1b 部分円筒の実施例

\begin{tabular}{|c|c|c|c|c|c|c|c|c|c|c|c|c|c|c|c|c|c|c|c|c|c|}
\hline 部分円簡 & $210^{\circ} \cdot L$ & 枌長さB & $7^{\circ} x d$ & $51 \pi^{\circ}$ & 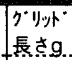 & ${ }_{* 1}^{L / d}$ & $\begin{array}{l}B / L \\
* 2\end{array}$ & $d / 9$ & $\begin{array}{l}L / f \\
* 4\end{array}$ & $\begin{array}{l}\text { 最大 } \\
\text { 部材趶 }\end{array}$ & $\lambda$ 弦ax & $\begin{array}{l}\lambda \max \\
\text { 紈热.... }\end{array}$ & \pm 境界 & 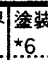 & 施工 & 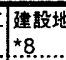 & $\begin{array}{l}\text { 用途 } \\
\pm 9\end{array}$ & 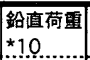 & |屋根面殓| & 最高高さh & |備考 \\
\hline $\overrightarrow{z-z}$ & $\mathrm{~m}$ & m & m & $\mathrm{m}$ & $\mathrm{m}$ & & & & & $\mathrm{mm}$ & & & & & & & & $\mathrm{kg} / \mathrm{m}^{2}$ & $\mathrm{~m}^{2}$ & $\mathrm{~m}$ & \\
\hline B01 & 23.0 & 32.0 & 2. & 11. & 4.6 & \begin{tabular}{|l|l|}
6 & 11.5 \\
\end{tabular} & 1.39 & 0.44 & 2.0 & 165 & 80 & 97 & 1 & 1 & 1 & & 1 & 115 & 1156 & 13.0 & \\
\hline $\mathrm{BO2}$ & 28.0 & 34.0 & 1.2 & 2. & 2.2 & 23.3 & 1.21 & 0.54 & 9.7 & 190 & 34 & 57 & & 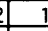 & 1 & & 1 & 110 & 979 & 8.2 & \\
\hline $\mathrm{BO3}$ & 55.8 & 68.2 & 3. & 5. & 3.6 & $\begin{array}{ll}615.9 \\
\end{array}$ & 1.22 & 0.97 & 11.2 & 267 & 39 & 91 & 2 & 1 & 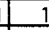 & & & 250 & 4311 & 21.0 & \\
\hline$B 04$ & 28.0 & 42.0 & 1. & 11. & 3.5 & \begin{tabular}{|l|l}
17.5 \\
\end{tabular} & 1.50 & 0.46 & 2.5 & 216 & 47 & 76 & & 1 & & & 3 & 175 & 1779 & 27.5 & \\
\hline B05 & 34.0 & 34.0 & 1.8 & 4. & 3.0 & 18.9 & 1.00 & \begin{tabular}{|l|l|} 
& 0.60 \\
\end{tabular} & 7.9 & 114 & 77 & 72 & 2 & 1 & 1 & 3 & 1 & 110 & 1482 & 14.8 & \\
\hline$B 06$ & 39.4 & 68.6 & 2. & 5. & 3.2 & 17.9 & 1.74 & 0.69 & 7.2 & 165 & 56 & 91 & 1 & 1 & 2 & & 2 & 150 & 2944 & 18.5 & \\
\hline $\mathrm{BO}$ & 22.9 & 31.0 & 1. & 3. & 3.1 & 15.3 & 11.35 & 0.48 & 6.0 & 114 & 81 & 69 & & 1 & 1 & & 1 & 100 & 762 & 14.1 & \\
\hline$B 08$ & 21.3 & 27.3 & 1. & 1. & 3.1 & 15.2 & 1.28 & 0.45 & 14.2 & 114 & 80 & 86 & & 1 & & & & 85 & 591 & 11.0 & \\
\hline$B 09$ & 26.8 & 44.0 & 1. & 3. & 2.5 & 5 & 1.64 & 0.52 & 7.9 & 139 & 52 & 72 & 2 & & 1 & & 1 & 113 & 1245 & 22.5 & \\
\hline$B 10$ & 50.2 & 66.0 & 2.7 & 7. & 4.4 & $\begin{array}{ll}418.6 \\
\end{array}$ & 1.31 & \begin{tabular}{|l|l|} 
\\
\end{tabular} & 6.4 & 216 & 59 & 73 & & 1 & 2 & 3 & 1 & 205 & 3413 & 36.0 & 施工時口ーラー支持 \\
\hline$B 11$ & 27.7 & 41.2 & 1.5 & 2. & 2.6 & 18.5 & 1.49 & 0.59 & 13.9 & 114 & 67 & 78 & & 1 & 1 & & 1 & 125 & 1304 & 11.2 & \\
\hline$B 12$ & 20.3 & 25.5 & 1. & 4.8 & 3.2 & 14.5 & 1.26 & 0.44 & 4.2 & 139 & 67 & 77 & & 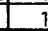 & & & & 140 & 585 & 11.9 & \\
\hline$B 13$ & 27.5 & 31.4 & 1.5 & 5. & 2.3 & 18.3 & 1.14 & 0.65 & 5.3 & 139 & 48 & 85 & & 1 & 2 & & & 115 & 940 & 14.7 & \\
\hline$B 14$ & 30.0 & 45.5 & 1. & 2. & 2.5 & 18.8 & 1.52 & 0.64 & 13.0 & 165 & 44 & 50 & 2 & 1 & 1 & & 1 & 130 & 1367 & 19.3 & \\
\hline$B 15$ & 26.0 & 34.0 & 1. & 3. & 2.3 & 17.3 & 1.31 & 0.65 & 8.7 & 165 & 41 & 64 & & 1 & 1 & & 1 & 130 & 876 & 12.9 & \\
\hline B16 & 28.0 & 33.0 & 1.8 & 2.2 & 2.8 & 15.6 & 1.18 & 0.64 & 12.7 & 190 & 43 & 69 & 2 & 1 & 1 & & 1 & 205 & 1060 & 13.8 & 多霄地域 \\
\hline$B 17$ & 28.2 & 64.8 & 1.8 & 5. & 3.0 & 15.7 & 2.30 & 0.60 & 5.5 & 216 & 41 & 49 & & 1 & 1 & & 3 & 84 & 1830 & 27.7 & \\
\hline$B 18$ & 44.4 & 75.0 & 2. & 1. & 4.0 & 18.5 & 1.69 & 0.60 & 29.6 & 267 & 43 & 57 & 2 & 2 & 2 & & 1 & 270 & 3330 & 10.1 & 多靁地域 \\
\hline$B 19$ & 20.5 & 29.3 & 1.2 & 1.8 & 2.0 & 14.6 & 1.43 & 0.70 & 11.4 & 139 & 42 & 77 & 1 & 1 & 2 & 3 & 1 & 110 & 602 & 11.6 & \\
\hline$B 20$ & 52.2 & 48.0 & 2. & 4. & 3.0 & 20.9 & 0.92 & 0.83 & 10.7 & 267 & 32 & 58 & 3. & 1 & 2 & 3 & 1 & 210 & 3230 & 21.3 & \\
\hline$B 21$ & 29.0 & 45.0 & 2. & 3. & 3.0 & 14.5 & 1.55 & 0.67 & 8.3 & 165 & 53 & 84 & & 1 & 2 & 3 & 1 & 130 & 1424 & 22.5 & \\
\hline$B 22$ & 20.0 & 32.0 & 1. & 3. & 2.5 & 14.3 & 1.60 & 0.56 & 6.7 & 139 & 52 & 74 & & 1 & 1 & & 1 & 220 & 625 & 17.6 & \\
\hline$B 23$ & 40.9 & 60.8 & 2. & 4. & 3.2 & 17.0 & 1.49 & 0.75 & 8.5 & 318 & 29 & 50 & 1 & 1 & 2 & 3 & 1 & 205 & 2576 & 17.0 & \\
\hline$B 24$ & 26.5 & 36.0 & 1.5 & 3. & 3.0 & 17.7 & 1.36 & 0.50 & 7.4 & 165 & 53 & 75 & & 1 & $\frac{1}{1}$ & 1 & & 85 & 1220 & 18.8 & \\
\hline B25 & 48.0 & 54.0 & 2.3 & 6. & 3.3 & 20.9 & 1.13 & 0.70 & 8.0 & 190 & 50 & 94 & & 1 & 1 & 1 & 1 & 120 & 2890 & 19.6 & \\
\hline 826 & 20.0 & 25.0 & 1.3 & 3. & 1.8 & 15.4 & 1.25 & 0.74 & \begin{tabular}{|l}
5.1 \\
\end{tabular} & 89 & 58 & 69 & at & 1 & 1 & 3 & & 130 & 550 & 19.7 & \\
\hline 827 & 87.1 & 57.1 & 3.2 & 5. & 3.4 & 427.2 & 0.66 & 0.96 & 17.4 & 318 & 31 & 83 & 2 & 2 & 1 & 3 & 1 & 340 & 5295 & 17.7 & 多霄地域旃工時口-ラー支持 \\
\hline$B 28$ & 40.6 & 41.6 & 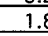 & 4.3. & 3.3 & 22.6 & 1.02 & 0.55 & 9.4 & 216 & 44 & 52 & & $\frac{5}{1}$ & & & & $\frac{745}{115}$ & 1739 & 20.5 & 3. \\
\hline$B 29$ & 26.0 & 41.0 & 1.2 & 2. & 2.3 & 21.7 & 1.58 & 0.52 & 10.0 & 101 & 68 & 67 & 2 & 1 & 1 & & 1 & 105 & 1074 & 12.5 & \\
\hline$B 30$ & 27.8 & 32.7 & 1.2 & 4. & 2.4 & 19.9 & 1.18 & 0.60 & 6.5 & 139 & 48 & 84 & 1 & 1 & 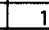 & & & 130 & 965 & 17.2 & \\
\hline B31 & 30.5 & 55.0 & 1.5 & 6.8 & 4.0 & 20.9 & 1.13 & 0.48 & 5.1 & 216 & 54 & 94 & & 1 & & & & 120 & 1696 & 13.9 & \\
\hline
\end{tabular}


$1500 \mathrm{~m}^{2}$ 以下の小規模のデータが大部分を占める（図4）。

\section{2 境界条件}

3.1で示した各形状の境界条件は、その支持方法によってピン支 持（バネ評価も含む）またはローラー支持からなる。さらに、4辺ま たは 4 点をピン支持とする場合や、ピン支持とローラー支持を組み合 わせた場合に分類できる。曲面版の境界条件はスラストや温度変化等 に対応すべく、面内方向をピン支持、“面外方向をローラー支持として いる。これらの境界条件には、施工中にローラー支持、施工終了後に ピン支持となる場合もある。

\section{3 . 3 部品}

システムトラスの部品は鋼管部材の径 $\phi 48 ＼mathrm{~ 申 355 （ S T K ~ 400 ） 、 ~}$ 接合部中核の径 $60 \mathrm{~mm} \sim 430 \mathrm{~mm} （ \mathrm{SM} 490 \mathrm{~A}$ 相当）、接合機構のボルト として径M12〜M76（F9T相当）を使用している4)。鋼管部材の座屈 長さは接合部中核の中心間距離とし、その座屈長さに対する部材の細 長比は圧縮材、引張材にかかからず160以下としている。接合部中核 は、個々の部材の設計軸力に対してボルトの許容引張力以下でねじ抜 けが起きないことや、複数の部材の軸力状態に対しても安全となるよ
うに設計している。ボルトサイズはM 200 まて製造できることを報告 しているいが、高張力鎆で造られている太径ボルトの場合、高軸力下 における勒性の確保及び熱処理等の品質管理の問題から、標準部品と しては最大ボルトをM76としている。これらの部品はシステムトラス を構成する部品の中から定められた設計手順に基づいて選定してい る。

3. 4 施工法

本実施例に使用されている施工法を分類すると下記のようになる。 システムトラスの施工中は支保工で支持されているが、支保工の位置 や設計条件によっては、施工時の応力・变形・反力が設計時に想定し たものより上回る場合もある。

1）総足場工法

システムトラスを架設するレベル近くまで作業用の固定の仮設足 場を設け、その上で建方する工法である。建方の自由度は高い が、足場費用は高くなる。

2 ) 移動足場工法

システムトラスを固定の足場ではなく、移動型の足場の上で建方

表1c 寄棟の実施例

\begin{tabular}{|c|c|c|c|c|c|c|c|c|c|c|c|c|c|c|c|c|c|c|c|c|c|}
\hline 寄楮 & $2 n n^{\circ} \cdot 1$ & 桁長さB & $7^{\circ} \mathrm{xd}$ & F12' $f$ & 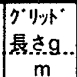 & $\begin{array}{l}\mathrm{L} / \mathrm{d} \\
* 1\end{array}$ & \begin{tabular}{|l}
$B / L$ \\
$* 2 \ldots$
\end{tabular} & $\begin{array}{l}d / g \\
* 3 . . .\end{array}$ & $\begin{array}{l}L / f \\
* 4\end{array}$ & $\begin{array}{c}\text { 侵大 } \\
\text { 部材怿. } \\
\text { mm }\end{array}$ & $\begin{array}{l}\lambda \max \\
\text { 弦㷊.... }\end{array}$ & $\begin{array}{l}\lambda \max \\
\text { 剑材.... }\end{array}$ & $\begin{array}{l}\text { 境界 } \\
* 5 \\
* 5 . .\end{array}$ & 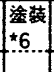 & $\begin{array}{l}\text { 施工 } \\
\star 7 \\
\therefore\end{array}$ & 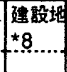 & $\begin{array}{l}\text { 用途 } \\
* 9 .\end{array}$ & 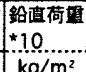 & 屋根面程 & 最高高さh & 備考 \\
\hline$\frac{T-z}{C 01}$ & 24.5 & 46.0 & 1.8 & 1.8 & 3.1 & 13.6 & 1.88 & 0.58 & 13.6 & 139 & 65 & 93 & 2 & 1 & 1 & 1 & 1 & 130 & 1309 & 14.6 & \\
\hline $\mathrm{CO2}$ & 34.5 & 44.6 & 2.0 & 3.3 & 4.3 & 17.3 & 1.29 & 0.46 & 10.5 & 190 & 66 & 77 & 2 & 1 & 1 & 1 & 1 & 130 & 1606 & 14.0 & \\
\hline $\mathrm{CO} 3$ & 18.6 & 51.0 & 1.8 & 1.1 & 4.2 & 10.3 & 2.74 & 0.43 & 16.9 & 139 & 88 & 91 & 2 & 1 & 1 & 1 & 1 & 145 & 988 & 12.0 & \\
\hline $\mathrm{CO} 4$ & 40.0 & 52.0 & 2.2 & 2.3 & 4.0 & 18.2 & 1.30 & 0.55 & 17.4 & 267 & 44 & 55 & 2 & 1 & 1 & 1 & 1 & 180 & 2098 & 17.5 & \\
\hline $\mathrm{COS}$ & 41.3 & 52.5 & 2.0 & 2.0 & 3.5 & 20.7 & 1.27 & 0.58 & 20.7 & 267 & 38 & 66 & 2 & 1 & 1 & 3 & 1 & 128 & 2201 & 15.3 & \\
\hline $\mathrm{CO} 6$ & 26.3 & 34.2 & 1.3 & 1.9 & 2.9 & 19.7 & 1.30 & \begin{tabular}{|l}
0.47 \\
\end{tabular} & \begin{tabular}{|l|}
3.8 \\
\end{tabular} & 139 & 60 & 63 & 2 & 1. & 1 & 3 & 1 & 125 & 943 & 16.2 & \\
\hline $\mathrm{CO}$ & 23.3 & 27.1 & 1.4 & 0.6 & 2.7 & 16.6 & 1.16 & 0.52 & 38.8 & 114 & 70 & 79 & 2 & 1 & 1 & 1 & 1 & 160 & 635 & 12.2 & \\
\hline $\mathrm{COB}$ & 22.3 & 38.3 & 1.5 & 1.4 & 2.3 & 14.9 & 1.72 & 0.65 & 15.9 & 114 & 59 & 85 & 2 & 1 & 1 & 3 & 1 & 135 & 908 & 22.8 & \\
\hline Co9 & 27.7 & 49.2 & 1.8 & 4.0 & 3.6 & 15.4 & 1.78 & 0.50 & 6.9 & 139 & 75 & 90 & 2 & 1 & 1 & 3 & 1 & 80 & 1667 & 14.7 & \\
\hline $\mathrm{C} 10$ & 33.4 & 52.5 & 2.2 & 2.9 & 3.8 & 15.2 & 1.57 & 0.59 & \begin{tabular}{|l|}
11.7 \\
\end{tabular} & 216 & 51 & 61 & 2 & 1 & 1 & 1 & 1 & 140 & 1753 & 14.5 & \\
\hline $\mathrm{C} 11$ & 18.4 & 30.8 & 1.8 & 2.1 & 3.0 & 10.2 & 1.67 & 0.60 & \begin{tabular}{|l|}
8.8 \\
\end{tabular} & 139 & 62 & 71 & 2 & 1 & 1 & 1 & 1 & 125 & 565 & 14.1 & \\
\hline $\mathrm{C} 12$ & 32.5 & 47.5 & 2.0 & 3.3 & 3.0 & 16.3 & 1.46 & 0.67 & 10.0 & 216 & 40 & 51 & 2 & 1 & 1 & 1 & 1 & 170 & 1576 & 17.4 & \\
\hline $\mathrm{C} 13$ & 19.5 & 30.0 & 1.7 & 3.9 & 2.5 & 11.5 & 1.54 & 0.68 & 5.0 & 89 & 83 & 95 & 2 & 1 & 1 & 1 & 1 & 145 & 592 & 19.9 & \\
\hline $\mathrm{C14}$ & 24.9 & 36.5 & 1.5 & 3.1 & 2.4 & 16.6 & 1.47 & 0.63 & 8.0 & 139 & 50 & 66 & 2 & 1 & 1 & 3 & 1 & 130 & 938 & 13.3 & \\
\hline C15 & 51.6 & 83.2 & 2.5 & 11.6 & 3.0 & 20.6 & 1.61 & 0.83 & 4.4 & 267 & 32 & 50 & 2 & 1 & 1 & 3 & 1 & 195 & 4332 & 23.1 & \\
\hline $\mathrm{C} 16$ & 24.6 & 58.3 & 1.7 & 3.1 & 2.0 & 14.5 & 2.37 & 0.85 & 7.9 & 216 & 27 & 46 & 2 & 1 & 1 & 3 & 1 & 425 & 1435 & 13.1 & 多墨地域 \\
\hline
\end{tabular}

表1d 曲面版の実施例

\begin{tabular}{|c|c|c|c|c|c|c|c|c|c|c|c|c|c|c|c|c|c|c|c|c|c|}
\hline 曲面版 & $\pi n^{\circ} \cdot L$ & 沐長さB & $7 \times d$ & j1ג'f & 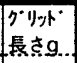 & \begin{tabular}{|l|}
$L / d$ \\
\pm 1
\end{tabular} & $\begin{array}{l}B / L \\
\ldots 2 \\
\ldots 2 . .\end{array}$ & $\begin{array}{l}d / g \\
\star 3\end{array}$ & $\begin{array}{l}L / f \\
* 4\end{array}$ & \begin{tabular}{|l|} 
最大 \\
部校嗤
\end{tabular} & $\begin{array}{l}\lambda \max \\
\text { 弦材..... }\end{array}$ & \begin{tabular}{|c|}
$\lambda \max$ \\
斜材.....
\end{tabular} & 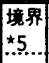 & 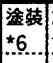 & 施工 & $\mid \begin{array}{l}\text { 建設城 } \\
\approx 8 \\
8\end{array}$ & 用途 & 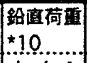 & 屋根面积 & 曼高高さh & 门備考 \\
\hline F゙ー夕 & $\mathrm{m}$ & $\mathrm{m}$ & $\mathrm{m}$ & $\mathrm{m}$ & $\mathrm{m}$ & & & & & $\mathrm{mm}$ & & & & & & & & $\mathrm{kg} / \mathrm{m}^{2}$ & $\mathrm{~m}^{2}$ & $\mathrm{~m}$ & 水平投影形状 \\
\hline D01 & 34.7 & 34.7 & 1.5 & 14.1 & 3.0 & 23.1 & 1.00 & 0.50 & 2.5 & 101 & 87 & 86 & 2 & 2 & 1 & 2 & 3 & 167 & 1620 & 29.4 & 4)田形 \\
\hline $\mathrm{DO2}$ & 70.0 & 70.0 & 1.5 & 13.0 & 3.5 & 46.7 & 1.00 & 0.43 & 5.4 & 318 & 32 & 31 & 2 & 1 & 1 & 3. & 3 & 110 & 4867 & 29.5 & 巴形 \\
\hline D03 & 74.0 & 74.0 & 2.0 & 14.7 & 3.0 & 37.0 & 1.00 & 0.67 & 5.0 & 165 & 53 & 61 & 2 & 2 & 1 & 1 & 1 & 145 & 4700 & 28.3 & 田形 \\
\hline D04 & 56.4 & 56.4 & 1.5 & 7.7 & 3.5 & 37.6 & 1.00 & 0.43 & 7.3 & 165 & 62 & 60 & 2 & 2 & 1 & 1 & 1 & 145 & 2720 & 21.7 & 巴形 \\
\hline D05 & 50.4 & 66.0 & 2.5 & 9.0 & 3.0 & 20.2 & 1.31 & 0.83 & 5.6 & 216 & 41 & 44 & 2 & 1 & 1 & 3 & 3 & 190 & 3650 & 23.1 & 短形 \\
\hline D06 & 33.7 & 39.2 & 2.0 & 3.0 & 2.8 & 16.9 & 1.16 & 0.71 & 111.2 & 190 & 43 & 50 & 2 & 1 & 1 & 3 & 1 & 130 & 1585 & 14.4 & 短形 \\
\hline D07. & 31.9 & 31.9 & 1.5 & 1.1 & 2.5 & 21.3 & 1.00 & 0.60 & 29.0 & 190 & 38 & 41 & 2 & 1 & 1 & 1 & 1 & 205 & 801 & 27.1 & 苗形 \\
\hline 008 & 57.3 & 70.0 & 2.5 & 4.7 & 3.1 & 22.9 & 1.22 & 0.81 & 12.2 & 267 & 34 & 69 & 2 & 2 & 1 & 2 & 1 & 170 & 4180 & 19.3 & 短形 \\
\hline D09 & 23.4 & 31.5 & 1.8 & 3.0 & 3.2 & 13.0 & 1.35 & 0.57 & 7.8 & 139 & 66 & 60 & 2 & 2 & 1 & 2 & 1 & 170 & 864 & 17.3 & 短形 \\
\hline D10 & 43.4 & 55.8 & 2.0 & 6.4 & 3.1 & 21.7 & 1.29 & 0.65 & 6.8 & 165 & 55 & 62 & 2 & 1 & 1 & 1 & 1 & 110 & 3152 & 22.4 & 矩形 \\
\hline D11 & 42.0 & 42.0 & 2.2 & 7.9 & 3.0 & 19.1 & 1.00 & 0.73 & 5.3 & 190 & 46 & 54 & 2 & 1 & 1 & 3 & 3 & 230 & 2236 & 12.8 & 姖形，多賞地域 \\
\hline $\mathrm{D} 12$ & 34.5 & 40.0 & 1.5 & 2.6 & 2.5 & 23.0 & 1.16 & 0.60 & 13.3 & 139 & 52 & 60 & 2 & 1 & 1 & 3 & 1 & 125 & 1488 & 16.0 & 短形 \\
\hline D13 & 44.5 & 95.4 & 2.5 & 16.1 & 3.6 & 17.8 & 2.14 & 0.69 & 2.8 & 318 & 33 & 54 & 2 & 2 & 1 & 2 & 3 & 170 & 3808 & 27.8 & 平田 \\
\hline D14 & 39.8 & 39.8 & 3.0 & 8.5 & 3.9 & 13.3 & 1.00 & 0.77 & 4.7 & 190 & 59 & 62 & 2 & 2 & 1 & 2 & 3 & 150 & 1584 & 38.2 & 矩形 \\
\hline $\mathrm{D} 15$ & 30.6 & 36.8 & 1.2 & 12.1 & 1.8 & 26.6 & 1.20 & 0.64 & 2.5 & 165 & 32 & 49 & 2 & 1 & 1. & 3. & 3 & 250 & 1546 & 21.5 & 可掼巴 \\
\hline $\mathrm{D} 16$ & 30.0 & 60.0 & 2.3 & 2.0 & 3.0 & \begin{tabular}{|l|}
12.8 \\
\end{tabular} & 2.00 & 0.78 & 15.0 & 139 & 63 & 82 & 2 & 2 & 1 & 1 & 3 & 300 & 1356 & 15.0 & 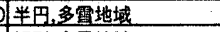 \\
\hline $\mathrm{D} 17$ & 36.0 & 36.0 & 1.6 & 5.5 & 3.0 & \begin{tabular}{|l|}
22.5 \\
\end{tabular} & 1.00 & 0.53 & 6.5 & 190 & 46 & 47 & 2 & 1 & 1 & 3 & 3 & 235 & 1726 & 14.3 & 矩形，垔罝地域 \\
\hline D18 & 39.8 & 60.0 & 2.1 & 3.2 & 3.0 & 19.0 & 1.51 & 0.70 & 12.4 & 267 & 33 & 32 & 2 & 1 & 1 & 1 & 1 & 170 & 2349 & 24.5 & 短形 \\
\hline $\mathrm{D} 19$ & 44.0 & 47.0 & 2.5 & 2.7 & 3.1 & \begin{tabular}{|l|}
17.6 \\
\end{tabular} & 1.07 & 0.81 & 16.3 & 267 & 34 & 59 & 2 & 1 & 1 & 1 & 1 & 200 & 2500 & 8.5 & 矩形 \\
\hline $\mathrm{D} 20$ & 63.7 & 99.0 & 3.2 & 6.3 & 4.5 & \begin{tabular}{|l|}
19.9 \\
\end{tabular} & 1.55 & 0.71 & 10.1 & 318 & 41 & 41 & 2 & 2 & 1 & 3 & 1 & 160 & 6684 & 24.2 & 聟形;沲工時口ーラー支持 \\
\hline $\mathrm{D} 21$ & 38.4 & 38.4 & 1.8 & 10.4 & 2.5 & \begin{tabular}{|l|}
21.3 \\
\end{tabular} & 1.00 & 0.72 & 3.7 & 139 & 52 & 83 & 2 & 2 & 1 & 2 & 1 & 160 & 2490 & 25.1 & I⿴囗十形 \\
\hline $\mathrm{D} 22$ & 22.5 & 35.0 & 1.5 & 1.7 & 2.3 & 15.0 & 1.56 & 0.65 & 13.6 & 101 & 67 & 64 & 2 & 1 & 1 & 1 & 1 & 160 & 2490 & .14 .2 & 短形 \\
\hline 注 & $\begin{array}{l}\text { *1:スパ } \\
\text { *2:枌長 } \\
\text { *3:デフ } \\
\text { *4:スパ } \\
\text { *5:境界 }\end{array}$ & 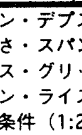 & 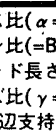 & 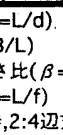 & & & & & & 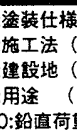 & (1:スポー & $\begin{array}{l}\text { 安,2:海岸 } \\
\text { - ツ施段, }\end{array}$ & $2: フ ゙$ & $\begin{array}{l}5+3 \\
5\end{array}$ & :多目 & 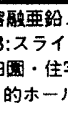 & $\begin{array}{l}\text { :宅· } \\
\text { ル) }\end{array}$ & 村地带〉 & & & \\
\hline
\end{tabular}


する工法である。足場が軽量のため移動が容易なこと、支持点の アンカー時に上下移動がないので作業が単純である。

3) スライディング工法

建物の一端に部分的に仮設足場を設け、この上で組上ったシステ ムトラスを治具を用いてスライドさせ、順次送り出して建方する 工法である。システムトラスの一部または全部をスライドさせる 際、境界条件が異なるため、部品サイズの変更を伴う場合が多 w。

4) ブロックエ法

システムトラスをいくつかのブロックに地組してから上架して建 方する工法である。

5) リフトアップ工法

システムトラス全体またはその一部を地上面で組み立てた後、シ ステムトラスを平行に支持点までの高さまで持ち上げて、支点を 受ける工法である。

\section{5 塗装仕様}

塗装は防錆と美装及び安全性などの機能を満たすために行われる。 その仕様はメンテナンスや経済性を考慮し、建築物の用途、機能にふ さわしいものを選定しなければならない。システムトラスの鋼管部材 の塗装仕様例として、一般塗装、溶融亜鉛メッキ塗装、重防触塗装の 3 種類に分類できる。重防触塗装はウレタン系やフッソ系、エポキシ 系等を使用するもので、太陽光線による紫外線劣化等の防止や耐久性 の向上のために使用されており、溶融监鉛メッキ塗装に代わる防錆塗 装として普及している。一般塗装は、JISで規定する錆止め塗装であ る。

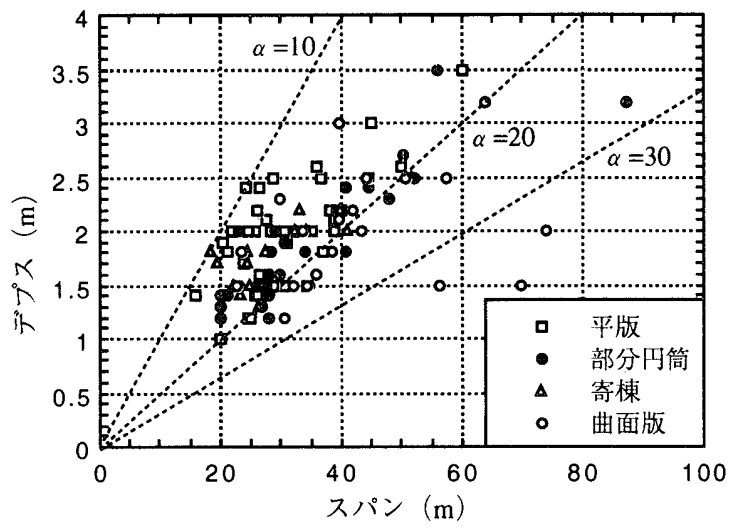

図5 スパンとデプスの関係

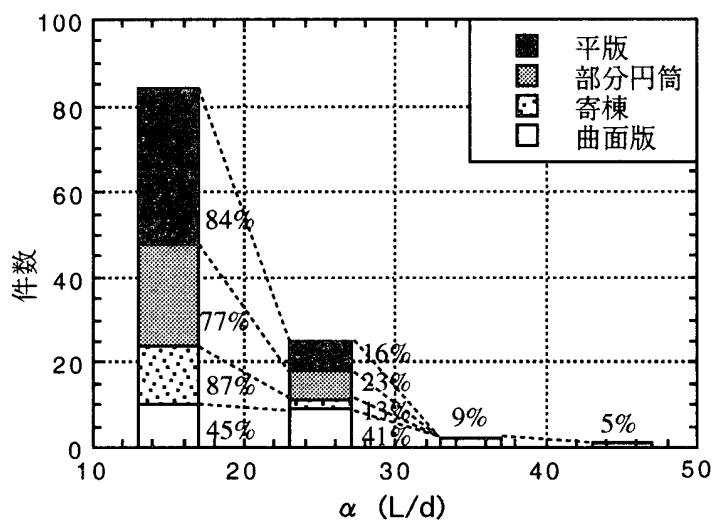

図6 各形状における $\alpha$ 分布

\section{4. 設計・施工情報の分析}

設計条件の適切な評価や合理的な構造物の性能を把握するため、3 節で示したシステムトラスの実施例において構造物の性能を規定する 設計・施工情報を定量的に分析する。

\section{1 グリッド形状}

平版、部分円筒、寄棟、曲面版の各形状におけるデプスは、スパン 16〜87mに対して各々1.0～3.5mの範囲に分布している（図5）。これ らの各形状とも鉛直荷重に対して長期 $1 / 300$ 、短期 $1 / 200$ の変形制限を 満たしており、十分な剛性を有している。各形状別にみると、平版、 部分円筒、寄棟、曲面版のスパン・デプス比 $(\alpha=\mathrm{L} / \mathrm{d})$ は $10<\alpha$ <20の範囲で、各々 43件中36件で $84 \% 、 31$ 件中 24 件で77\%、16件中 14件で87\%、22件中10件で45\%を占める。20< $\alpha<30$ の範囲で、各々 43 件中 7 件で $16 \%$ 、31件中 7件で $23 \%$ 、16件中 2 件で $13 \%$ 、22件中9件 で41\%を占める（図6）。特に、曲面版は他の形状に比して $20<\alpha<$ 30の範囲に多く分布している。曲面版は面内剛性が高いので、スパン に対してデプスを小さくすることができる傾向を示している。

グリッド長さは2 4mの範囲に多く分布する（図7）。これは、下 部構造の柱芯々間距離が5〜9mの範囲に分布し、支点を柱上部に配置 できるようにグリッドを 2 分割、3 分割等に割り付けているためであ る。すなわち、システムトラスの支点を柱位置に合わせることで、シ ステムトラスに作用する荷重を下部構造にスムーズに伝達し、下部構 造の経済性に寄与することになる。また、グリッド形状と美的要素、 細長比の関連は後で詳細に述べるが、仕上材及び母屋材の強度とスパ ン等の影響も受ける。

部分円筒、寄棟、曲面版の各形状のスパン・ライズ比 $(\gamma=\mathrm{L} / \mathrm{f})$

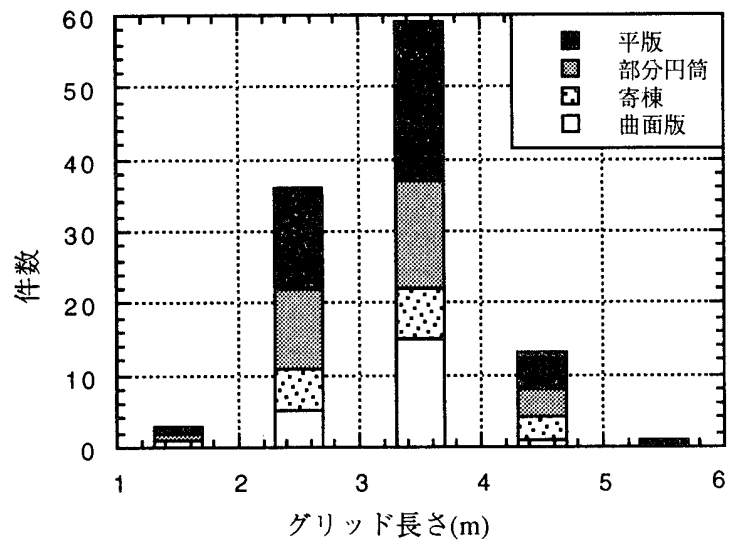

図7グリッド長さの分布

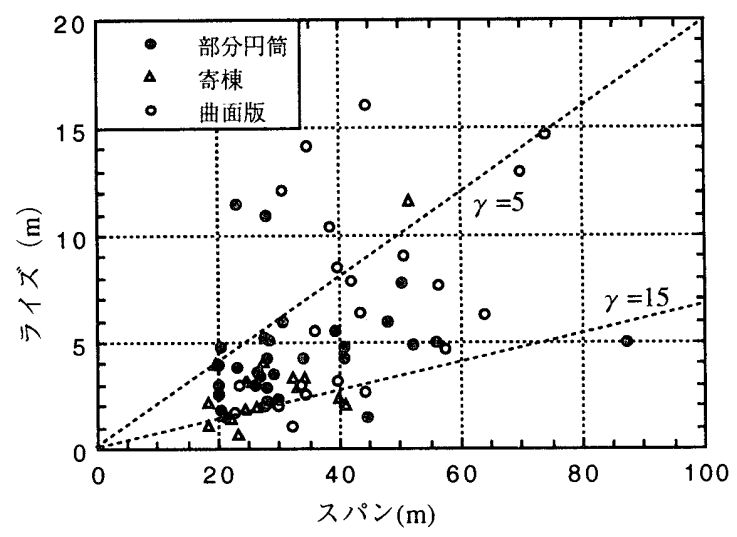

図8スパンとライズの関係 
は、5〜15の範囲に多く分布している（図8）。ライズを決定する要因 として、構造上の合理性のほか、システムトラスを使用している建築 物の必要有効高さや水勾配等の意匠上の制約と経済性が考えられる。 4. 2 境界条件

平版、部分円筒の境界条件における 4 辺支持は、表1aに示すごと く43件中 39 件で $91 \% 、 31$ 件中 14 件で $45 \%$ を占めている。寄棟と曲面 版にいたっては全て 4 辺支持である（図9）。4 辺支持の多くを、 面外方向をローラー支持、面内方向をピン支持としているのは、シ ステムトラスの立体効果により、面外方向を移動自由にすることで スラストカの発生を押え、下部構造への荷重の負担を軽減している ためである。下部構造は鉄骨造または R C 造であり、面内方向にラ ーメン架構となっている場合が多く、上記の条件をとることにより システムトラスから作用する荷重を容易に負担できることになる。 平版、部分円筒の境界条件における 2 辺支持は、43件中 3 件で7\%、 31 件中 17 件で $55 \%$ を占める。これは妻面の下部構造をシステムトラ ス支点まで立ち上げれない場合等の理由によるものである。また、 屋根構造により 2 つ建物の間をつなぐ場合、システムトラスは両 者の建物の地震時における強制変形を受けないように一方向をピン 支持、一方向をローラー支持の 2 辺支持のものもある。

4. 3 部品

\section{1）鋼管部材}

周辺部が単純支持された平版システムトラスに鉛直荷重が作用し た場合、弦材の最大軸力はスパン中央部に生じる。この最大軸力の 大きさは単純梁の理論による最大モーメントM から（1）式で示さ れる。

$$
M=\frac{s L^{2}}{8}, N=\frac{M}{d}
$$

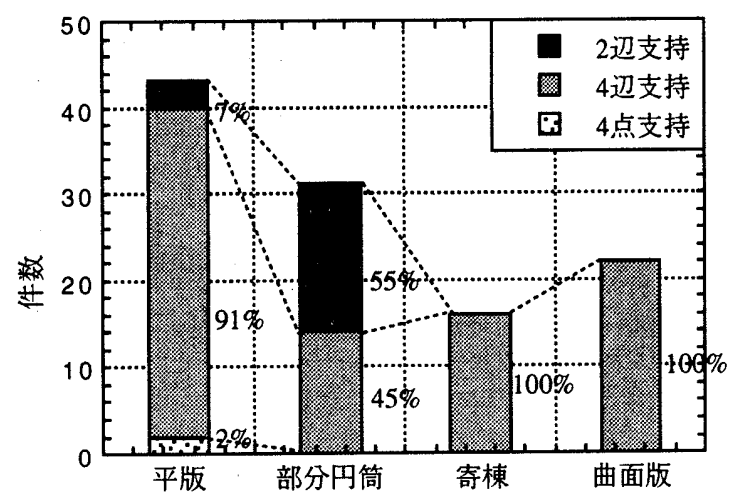

図9境界条件の分布

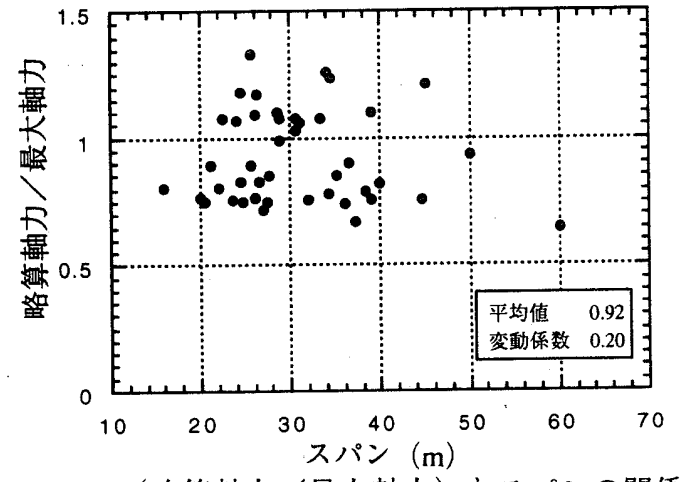

図10（略算軸力／最大軸力）とスパンの関係
ここで、

最大軸力：N ( t $)$ 、スパン $: \mathrm{L}(\mathrm{m})$ 、桁長さ：B (m)

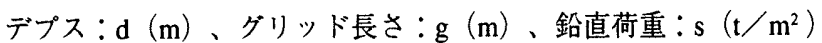
最大軸力は力が両方向に流れるとして辺長比（=B／L）による換算 係数 ${ }^{10)}$ (表2）を用いると（2）式で示される。

$$
\mathrm{N}=\frac{\mathrm{s} \mathrm{g} \mathrm{L}^{2}}{8 \mathrm{~d}} \eta
$$

ここでは、（2）式を用いて平版に扔ける略算最大軸力と害施例 の最大軸力の比較を試みる（図10）。（2）式による略算最大軸力 は、平版において鉛直荷重によって支配される部材が多いが、部材

表 2 辺長比 (=B/L) による最大軸力の換算係数 $\eta$

\begin{tabular}{|c|c|c|c|c|c|}
\hline $\mathrm{B} / \mathrm{L}$ & 1.0 & 1.1 & 1.2 & 1.3 & 1.4 以上 \\
\hline$\eta$ & 0.6 & 0.7 & 0.8 & 0.9 & 1.0 \\
\hline
\end{tabular}

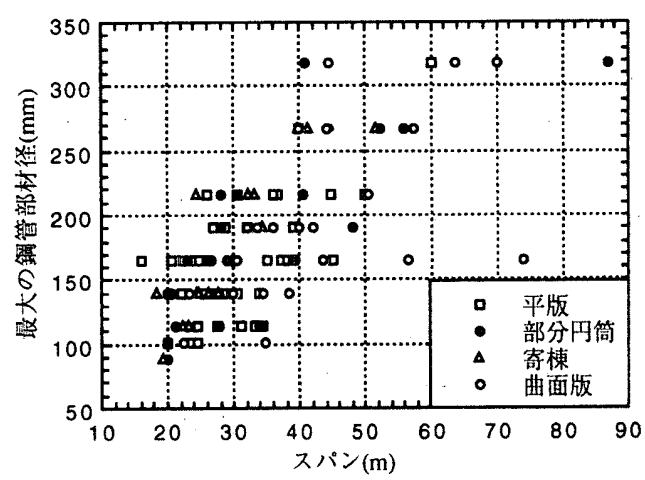

図11 スパンと最大の鋼管部材径の関係

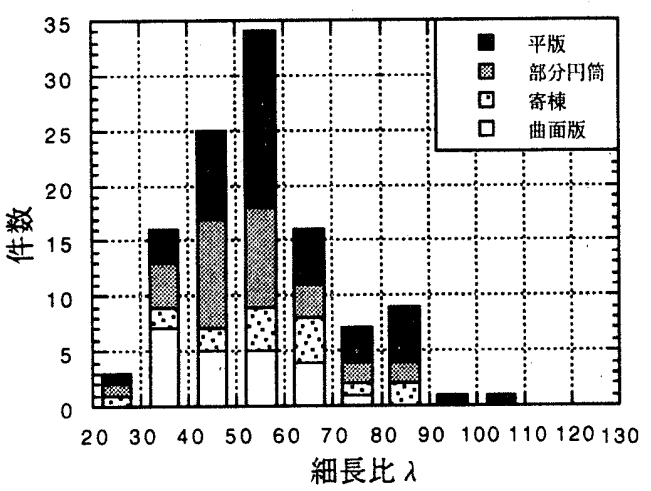

a) 弦材の最大細長比

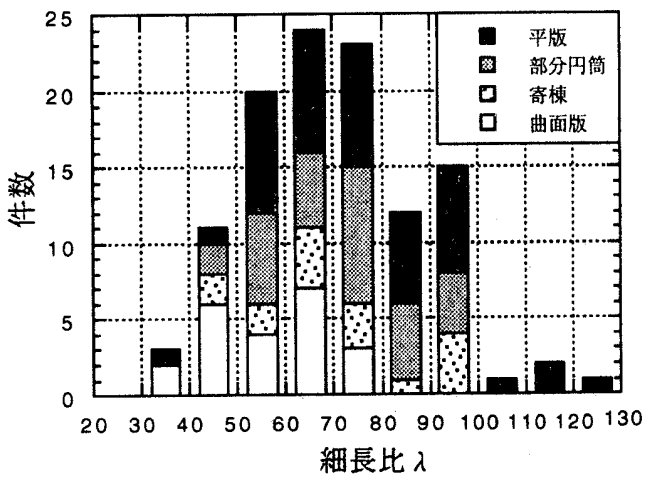

b）斜材の最大細長比

図12部材の最大細長比の分布 
配置、支点の位置及び個数等の影響により、実施例の最大軸力に対 してその值は土約40\%の範囲にばらつく傾向にある。

平版、部分円筒、奇棟、曲面版における最大の鋼管部材径とスパ ンの関係を図11に示す。各形状における最大の鋼管部材径は、グ リッド形状、境界条件の相違等の影響により、各スパンに対してば らつく傾向にある。平版、部分円筒、寄棟の最大の鋼管部材は、弦 材においてスパン中央、斜材において支点近傍において配置される 傾向にある。曲面版のうち、水平投影が円や楕円の場合における最 大の鋼管部材は、弦材において円周方向の最下層に、斜材において 支点に取りつく最下層に配置される傾向にある。また、曲面版のう ち、ライズが小さく、水平投影が矩形の場合における最大の鋼管部 材の配置は、平版、部分円筒、寄棟と類似の傾向を示している。最 大細長比 $\lambda$ は、 $30<\lambda<100$ の範囲で9 $6 \%$ を占める。これらのう ち、弦材において $50<\lambda<60$ 、斜材において $60<\lambda<80$ の範囲に最 も多く分布している（図12）。また、 $\lambda$ が100< 布するものは、表1 a 〜 d 示すごとく $\Phi 76 〜 \Phi 114$ の細径部材であ り、部材長が $3 \mathrm{~m}$ を全て超えている。このように最大の鋼管部は、 各形状に対して共に圧縮材として有効な断面となっている。

一方、鋼管部材の種類は各実施例において3〜7種類であり、

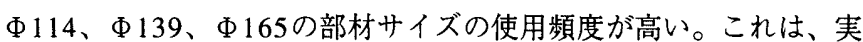
施例に示した制約条件においてスパンの大小にかかわらず、応力な りに段階的に部材が選定されていることによるものである。

2) グリッド形状と使用部品

グリッド形状はシステムトラスの使用部品を決定するための重要 な要素となる。その使用部品は強度を満たし、部品の干渉を生じな いように選定されなければならない。既に、著者らは、デプス・グ リッド長さ比 $(\beta=\mathrm{d} / \mathrm{g})$ が1.2以上または 0.5 以下に使用されるグ

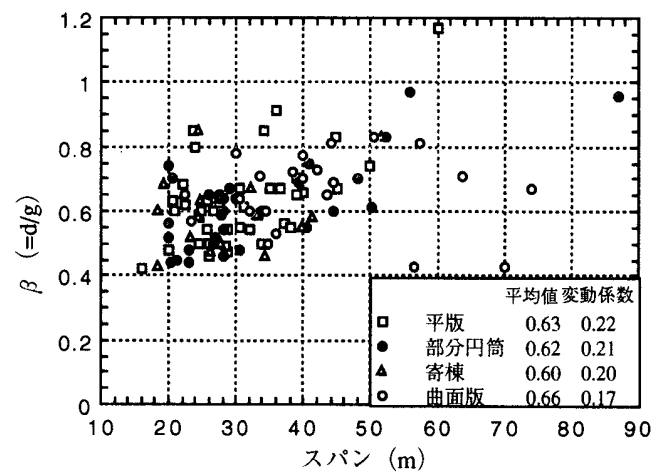

図13 スパンと $\beta$ の関係

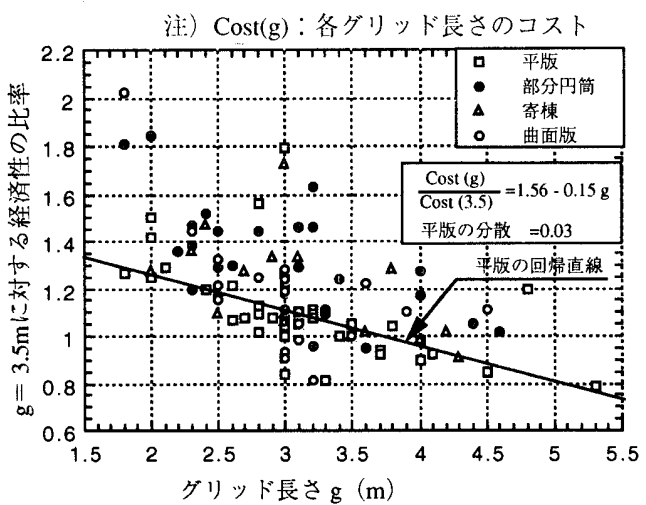

図14 グリッド長さ $\mathrm{g}$ と経済性の関係

リッド形状の場合、部品サイズは、酎力よりも競り合い角度や進入 角度等の部品の干渉によって決定される割合が多くなることを報告 している(2)。本実施例に㧈いて平版、部分円筒、寄棟、曲面版の 各形状とも、 $\beta$ が $0.4<\beta<0.5$ の範囲で $21 \% 、 0.5<\beta<0.9$ の範囲で $75 \% 、 0.9<\beta<1.2$ の範囲で4\%を占めることから、部品サイズの干 涉によって部材断面が決定される割合は少ないと考えられる（図 13）。なお、各形状の $\beta$ の平均值は $0.60 \sim 0.66$ 、変動係数は 0.17 0.22 示している。一方、グリッド長さを小さくし、均一な部材配 置とすれば、部品サイズのバランスが良く見える。しかし、 を超えるか、または、0.4より小さい場合、斜材と弦材が干渉し接 合部中核のサイズが大きくなるため、鋼管部材との美的なバランス を維持できなくなる場合が多い。

3）グリッド形状と経済性

部品サイズは、強度と干渉の他、経済性を考慮してを選定しなけれ ばならない。平版、部分円筒、寄棟、曲面版の各実施例のコストを各 形状におけるグリッド長さ $\mathrm{g}=3.5 \mathrm{~m}$ に対する割合として、グリッド長 さと経済性を比較する。各形状においてばらつきはあるものの、グ リッド長さが大きくなるに連れて経済的となる傾向を示す（図

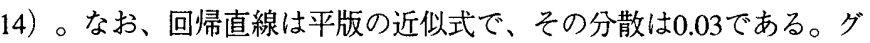
リッド長さが大きくなると、鋼管部材の座屈耐力が小さくなり、部材 サイズは大きくなる。しかし、接合部中核及び接合機構の経済性に占 める割合が大きく、それらの部品数が減少し安価となるため、このよ うな傾向を示すと考えられる。

4. 4 施工法

施工法において、総足場工法が $85 \%$ で最も多く、続いて移動足場 工法 $9 \%$ 、スライディング工法 $4 \%$ 、ブロック工法 $2 \%$ の順となる（図 15）。形状別にみると、寄棟、曲面版が全て総足場工法となってい る。これは総足場工法における足場の高さが建築物の位置によって異 なり、足場の盛り変えを多く必要とすることが大きな要因の一つとし

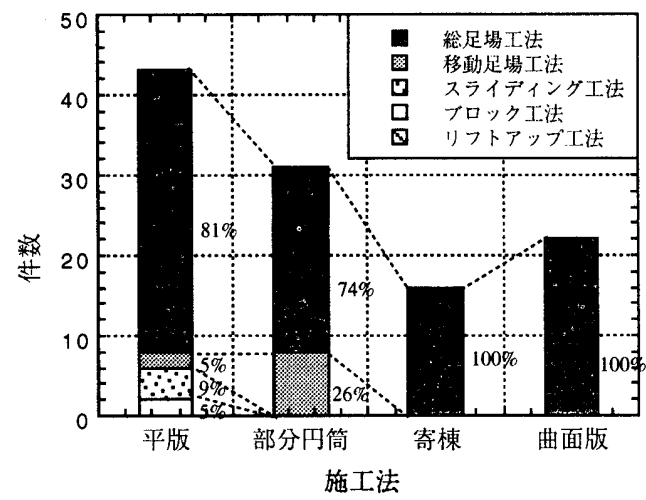

図16各形状における施工法の分布

ブロック工法 $2 \%$

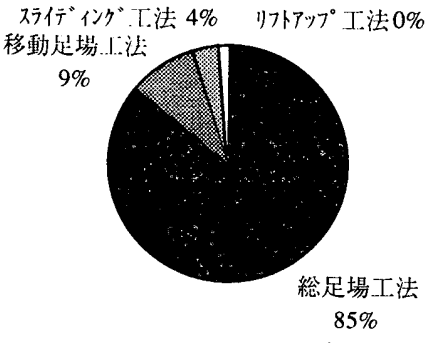

図15＼cjkstart施工法の分布

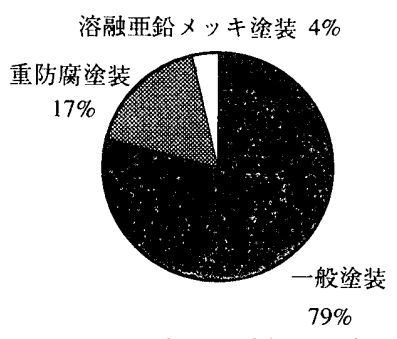

図17 塗装仕様の分布 
て挙げられる（図16）。総足場工法は足場を最も多く必要とするもの の、平版、部分円筒に占める割合が各々 43 件中 35 件で $81 \% 、 31$ 件中 23 件で74\%を占める。これはシステムトラスの施工の他、屋根工事や天 井工事、設備工事、塗装工事等に利用できることやそれらの工事の一 部を並列に進行することで工期を短縮できる等の理由によるものであ る。平版では移動足場工法が43件中 2 件で5\%であるが、部分円筒にお いては31件中 8 件で26\%を占めている。部分円筒では、妻面または析 面の軒高さが一定となり、足場の上下の調整が不用となるからであ る。スライディング工法は、平版で43件中 4 件で $9 \%$ 使用されている。 足場が増えて不経済になる場合や重機が建築物によりつけできない場 合等の制約条件下で限定的に使用されている。ブロック工法は平版に おいて43件中 2 件で5\%であり、4点支持の境界条件等に使用されてい る。リフトアップ工法は、ここで取り上げた実施例の中には採用され ていなかった。これらのことから、施工法は、屋根形状、建築物の制 約条件、工期、経済性によって決定されていることが分かる。

\section{5 塗装仕様}

塗装仕様において、一般塗装は79\%で最も多く、続いて重防触塗装 17\%、溶融亜鉛メッキ塗装4\%の順となる（図17）。これは、システ ムトラスを使用した建築物の用途として体育館等の屋内施設が多いこ とや経済性（一般塗装：重防触塗装：溶融亜鉛メッキ塗装＝1：1.5

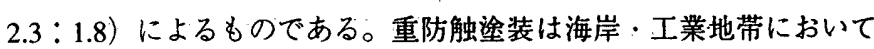
13件中 10 件の $77 \%$ を占めるが、市街地では56件中 7 件の $12 \%$ 、田園 · 住宅・農村において43件中2件の5\%である。溶融亜鉛メッキ塗装は海 岸・工業地带において13件中3件の23\%を占めるが、市街地において 56 件中 1 件の $2 \%$ にすぎず、田園・住宅・農村では使用されていなかっ た（図18）。これらのことから、塗装仕様は、建築物の用途、建設地 の条件、経済性によって決定されていることが分かる。

\section{5. 結論}

著者らが手がけたシステムトラスの実施例における設計・施工情報 の統計的分析の結果、次のようなことが明らかになった。

1）スパン・デプス比 $(\alpha=\mathrm{L} / \mathrm{d})$ を平版、部分円筒、奇棟において $10<\alpha<20$ 、曲面版において $10<\alpha<30$ の範囲で使用すれば、鉛 直荷重に対して長期 $1 / 300 、$ 短期 $1 / 200$ の変形制限を满たす設計を 行うことができる。

2）平版、部分円筒における境界条件の 4 辺支持は、各々 $91 \% 、 45$ \%、2 辺支持は、各々 $7 \% 、 55 \%$ 占めている。また、奇棟と曲面 版の境界条件はすべて 4 辺支持となっている。

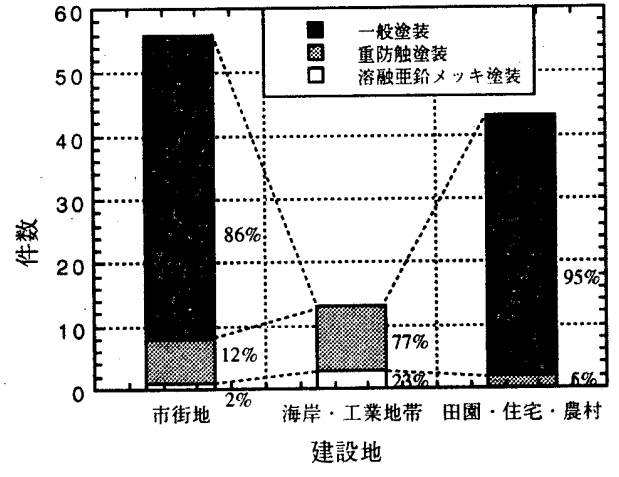

図18建設地と塗装仕様の分布
3）平版、部分円筒、奇棟、並びに曲面版で水平投影が矩形の場合の 最大の鋁管部材は、弦材においてスパン中央、斜材において支点 近傍において配置される傾向にある。また、曲面版のうち、水平 投影が円や棈円等に使用されている最大の鋼管部材は、弦材にお いて円周方向の最下層に、斜材において支点の取りつく最下層に 配置される傾向にある。

4）鋼管部材の最大細長比は $30<\lambda<100$ の範囲で $96 \%$ を占め、圧縮 材として有効な断面となっている。また、鋼管部材の種類は 各

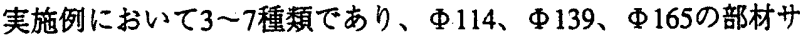
イズの使用頻度が高い。

5 ）デプス・グリッド長さ比 $(\beta=\mathrm{d} / \mathrm{g}) を 0.5<\beta<1.0$ の範囲で使 用すれば、部品の選定にあたって部品の干涉による影響は少な w。

6) 平版、部分円筒、奇棟、曲面版の各形状とも、接合部中核及び接 合機構の経済性に占める割合が大きく、グリッド長さが大きくな ると、部品数が減少するため、経済的になる傾向を示す。

7 ）施工法において、総足場工法が85\%と最も多く、続いて移動足場 工法9\%、スライディング工法4\%、ブロック工法 $2 \%$ の順となる。 これらは、屋根形状、建築物の制約条件、工期、経済性によって 決定されている。

8）塗装仕様において、一般塗装が79\%と最も多く、続いて重防触筀 装17\%、溶融垔鉛メッキ塗装4\%の順となる。これらは、建築物 の用途、建設地の条件、経済性によって決定されている。

9) 本論で示したシステムトラスにおける設計・施工情報のデータ ベースは、システムトラスに限らず、スペースフレームとしても 設計条件の適切な評価や合理的な構造物の性能を把握するのに役 立つと考えられる。

\section{参考文献}

1）坪井義勝（研究者代表）：スペースフレーム（立体格子構造）の設計・解 析·施工, 1982 年度文部省科学研究費補助金, 総合研究 (B) 研究報告萖,1983 年 3 月

2) Z.S.Makowski : Analysis,Design and Construction of Braced Domes, PublishedGranada Publishing, 1984

3）川合廣樹, 岩田衛, 白井貴志：システムトラス構法計画成立に関する論証,日 本建築学会計画系論文報告集, pp.51-59, 1988年 8 月

4）新日本製鐵株式会社：NSトラス標準部品，建設省東住指発第393号，1993 年9月

5）鹿島出版会：スペースストラクチャーの設計と奏例, 1971年

6）斎藤公男：スペース・ストラクチヤーのデザイン,カラム, No.83 pp.5-56, 1982 年. 1 月

7）日本建築学会,空間骨組小委員会：二層立体ラチス構造の解析・設計・施工， その現状と問題点, 1992年11月

8）田中淳夫：評定からみたシステムトラス構造についてビルディングレタ一, No.225 pp.1-7, 1988年4月

9）岩田衛, 藤田正則, 米田雅子, 和田章：システムトラスにおける設計・加工・ 施工情報に関する研究, 日本建築学会構造系論文報告集, pp.191-200, 1994年6 月

10）岩田䓊：はじめてのシステムトラス,建築技術, 1996年6月

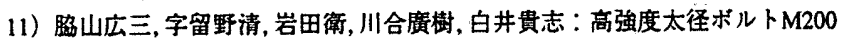
の製造に関する検討，日本建築学会学術講演梗概集（関東）,C, pp.927-928， 1988 年 10 月

12）藤田正則, 岩田衛：システムトラスの部品選定に関する一考察, 日本建築学 会学術講演梗概集, C-1, pp.155-156, 1995年8月

（1996年11月10日原稿受理，1997年5月26日採用決定） 